\title{
Artificial Life and Romantic Brides
}

von Michael Andermatt

In: Romantic Prose Fiction. Edited by Gerald Gillespie, Manfred Engel and Bernard Dieterle. Stanford University / University of Oxford / Université de Haute Alsace, Mulhouse. Amsterdam 2008 (=A Comparative History of Literatures in European Languages XXIII), S. 204-225.

Artificial humans, or androids (from the Greek "anér", gen. "andrós", meaning person, man), have been part of European literature since the classical age (cf. Völker [1971]; Drux [1988]). In Homer's Iliad $(18,417-21)$ Hephaestus, the god of fire and metallurgy, surrounds himself with artificially created golden virgins to serve him; in Ovid's Metamorphoses $(10,243-97)$ the love of the Cypriot artist Pygmalion for the statue of a woman he himself has created brings her to life; and Prometheus animates men and women whom he has shaped out of clay and water (Metamorphoses 1, 82-88). The literature of late antiquity and the medieval period is littered with animated statues, mechanical attendants or warriors, and talking heads. In Jewish legend we find the tradition of the Golem, a servant made of clay who is brought to life. From the Renaissance we are familiar with humans produced pseudo-scientifically from alembic vessels, the so-called homunculi (even Goethe dreams up a homunculus in Faust II), as well as biological hybrids like the mandrake root, which is part plant, part human. In the eighteenth and nineteenth centuries, technological advances lead to the appearance of automata or mechanical creatures, and Mary Shelley's Frankenstein gives rise to the monster produced by medical science. Finally, the twentieth century, especially in science fiction novels, is awash with robots, mutants, clones and cyborgs. It seems as though the creation of artificial beings lies at the very heart of human fantasy.

Traditionally, manufactured humans are either women or servants (cf. Gendolla [1984], 265; Drux [1988], XI). There are thus two primary variations on the main theme: the artificial woman, or, more accurately, the artificial bride, and the artificial menials. In both cases, however, the creators of these androids as a rule are men, particularly artists, magicians or scientists, who, as figures of mastery, are experienced and adept in cultural practices. In the creation of artificial beings, especially the artificial woman, the male master attempts to possess the zone of "nature" or the "other" of rationality. The body, fantasy, desire and emotions are thus brought under the influence and supervision of culture and civilization (cf. Böhme/Böhme [1985]). In nearly all of the texts in which this theme appears, however, the creator sooner or later loses control over his creation, and the artificial being turns against its creator, bringing destruction (cf. Drux [1988], XIIIff).

How does this thematic function in Romantic prose fiction? Mary Shelley's Frankenstein alone would justify the argument that this motif plays an important role in Romanticism. In quantitative terms, however, it shows up much less frequently than one might think. It appears above all, and almost exclusively, in German Romanticism, from which its influence spreads first to France and then to the literature of the entire world. The following overview begins with the development of the motif in German Romanticism and then discusses its formulation in other Romantic literature. For reasons of space, I will limit myself largely to the thematic strand of the artificial bride, leaving aside the artificial servants and companions, which in Romanticism since Jean Paul have largely served as vehicles of philistine critique (cf. Sprengel [1977]). For the same reasons, I must also leave aside the theme of the painted beloved and her animation (cf. von Matt [1971], 38ff), which is closely related to the motif of the artificial bride.

The animated statues, robots and monsters in German Romantic narratives, as I will argue throughout, tell us something about the Romantic conception of the mutually embedded relationship between art and life. In the works of the German Romantics, the theme of artificial humans thus has an essentially auto-poetic, or self-reflexive, function (cf. Schmitz-Emans 1993, 168f). It corresponds in exemplary fashion with Friedrich Schlegel's idea of transcendental poetry, which should always be "poetry and simultaneously the poetry of poetry" (Schlegel [1985], 50). In the theme of artificial life as well as in transcendental poetry, the observation of the world is integrally bound up with the observation of art and the self (cf. Kremer [1996], 8ff). 
The grounding paradigm for the creation of the artificial bride appears in the myth of Pygmalion, the oldest and best known version of which stems from Ovid's Metamorphoses (10, 243-97). The sculptor Pygmalion, burning with passion for the statue he himself has created, entreats the goddess of love Venus to bring the statue to life. What is decisive is that Pygmalion creates the ivory statue because he has been deeply disappointed in an actual, human woman. Out of this disappointment with everyday existence, Pygmalion turns to art, which alone can fulfill his demands on life and love (cf. Ovid 1988, 10, 243-49). The artificial woman thus replaces the real woman, surpassing her in external and internal beauty. Even though Pygmalion requires the help of Venus to animate the statue, it is nonetheless the "male" spirit and art itself that compensate for the deficiency of "female" nature and thereby gratify the desire of the man. The process of creating humans by means of art therefore involves an auto-erotic and narcissistic aspect. The degree of culture achieved in this moment is a celebration of its own magnificence, conceived in terms of a self-love based on differentiation from its rival, nature. It comes as no surprise that the German Romantics, with their messianic ideas of art that border on the religious, should zealously seize on and reformulate this notion of art's primacy over life.

In addition to Pygmalion there is a second thematic tradition, the Venus ring, which plays a major role in narratives about the bride of stone (cf. Mühlher [1957]). The theme of the Venus ring involves a fiancé who, in a reckless moment, places his engagement ring on a statue of Venus; the statue is thereby brought to life, then to appear on the wedding night as a ghostly presence who supplants the real bride at her husband's side. The German Romantics apparently knew of this motif from Kornmann's Mons Veneris (1614), but it is in fact older, belonging to the legends of late antiquity, from which it passed on to medieval chronicles like that of Wilhelm von Malmesbury (1125) (cf. Weschta [1916], 4-13; Brunel [1969], 12f). As in the Pygmalion myth, the Venus ring involves the replacement or displacement of the real woman by the artificial woman figured as a statue. In this cycle, however, the artificial woman Venus is imagined to be dangerous and depraved. The medieval Christian sources even place the pagan Venus statue in the same league as the devil, for Venus symbolizes the all-consuming carnal passions of heathen, barbaric antiquity. Her reanimation consequently represents the dangerous return of an older culture that has been conquered, or, as Sigmund Freud puts it, the uncanny return of the repressed (cf. Freud [1970]). Whereas Pygmalion's animated statue embodies a male fantasy of desire, the pagan Venus, reanimated out of marble, represents a fantasy of fear and horror.



Clemens Brentano's novel Godwi oder Das steinerne Bild der Mutter (Godwi, or the stone image of the mother), 1800/02, is one of the earliest texts of German Romanticism to develop the theme of bringing a statue to life, and it does so in doubled form. In this text, the animation of the statue thematizes the sublimation of pleasure and sorrow in the apotheosis of art.

One of the two marble statues in the novel, as the title suggests, is the statue of Godwi's mother; the other is the allegorical grave monument of a prostitute. The two statues represent the cornerstones, or the "two beautiful poles" (Brentano [1973], 373), of Godwi's life. Moreover, they figure the development of the protagonist, and of the novel Godwi itself. Brentano's use of the statue takes femininity as an allegory for the development of the Romantic hero. The marble statues in Godwi thus show the way, programmatically, that the male Romantic biography should take.

The maternal statue in Godwi reflects the pain and impossibility of carnal love, strengthened by the incest taboo. As a child Godwi enters the garden at night and attempts to awaken the mysterious statue (which he does not know to be of his mother) from her paralysis into life:

And it seemed that that deeply mourned / Woman of marble, / Which I had always violently loved, / By the lake in the moonlight, / Began painfully to extend herself, / To long for life. / . . . It dragged me from the spot, as though I were drawn by phantoms / To the pool, and my eyes stared / At the white statue, which seemed to await me, / So that I threw my heated arms around it, / And pressed life into the cold breast. (Brentano [1973], 145)

Though this passage suggests that the statue is about to come to life, this does not in fact occur, for Godwi fails in his attempt. He mistakes his way in the dark, falls into the pool, loses consciousness and nearly drowns. Godwi thus does not succeed in alleviating the suffering of the statue, freeing her 
from her paralysis, and winning her as a beloved. As a rigid, pallid statue, the figure of the mother embodies Godwi's inadequacy and failure in love. Subsequently, the desired woman becomes ever more unattainable, since iconographically she moves away from the figure of the beloved to the figure of the Christian mother of pain, Mary, the "sacred image" (Brentano [1973], 147) of the "mother of God" (Brentano [1973], 330).

In Brentano's Godwi, the myth of Pygmalion undergoes a typically Romantic shift in meaning. The ardor of love does not bring the statue to life, but rather resituates it as an unattainable ideal. In the end, in an ironic negation of the thematic tradition, life and death are in fact reversed; the new Pygmalion Godwi, impelled by his early experience with the maternal statue, finds himself leaving his various lovers only to transfigure the most carnal of them, beyond death, into works of art as statues.

This is where the second of the novel's marble statues comes in, the grave monument to the prostitute Violette. The replacement of non-life with life, which Brentano's Godwi takes from the Pygmalion myth, is figured in Violette's grave monument as the Romantic apotheosis of art, that is, as the intensification of life through poetry. At the feet of this statue, the narrator Maria experiences the only animation possible in Godwi: animation through the medium of art. Brentano thus overlaps the erotic desire of Maria with the process of artistic recognition; by means of this intensified Romantic love the statue is animated paradoxically as the work of the poet:

As it [the statue] stood before me, as though arisen from the darkness, radiant, fully-formed and unconstrained, it reached out to me and demanded of me, what it was; it violently desired me to recognize it, and joy filled my breast that I did recognize it, and that in the darkness it and I was its desire, and that attainment came with the light, in me and in it. (Brentano [1973], 295)

In a visionary love dialogue with the "recognized" statue, Violette's life is revealed to Maria as a transformation through art. Maria addresses the desired monument in tones of both love and poetry, first in allegorical prose, then ascending to sonnets and a canzona (cf. Brentano [1973], 295-301). The dead Violette is thus doubly animated through art: first as sculpture and then in Maria's vision as poetry. Mortal life moves paradoxically beyond death, transformed into the higher life of art. The focus of this process lies in the image of the gaping "wound" (Brentano [1973], 296), which comes to stand in for the devalued genitals of the beloved, raising the dead body of the woman, through her own mystique of blood and suffering, to the newly animated body in art.

Brentano's animation of the statue gains its transcendental poetic heightening from the fact that in the end Maria presents his verses as a work of art to Godwi. The versification of Violette draws the characters of the novel into a discussion about the essence of poetic transformation. Through this Godwi succeeds in recognizing that life has also turned him to stone, out of which the poet Maria can create a work of art, namely the novel Godwi itself, which the reader holds in his/her hands: "You could, if you were to keep company with me for some time, develop my history from me, from the monument of my life" (Brentano [1973], 303). In a move typical of the Romantics, Brentano's new Pygmalion no longer transforms his beloved from art into life; rather, in reverse, he accedes to art together with the beloved.

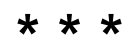

In the same period as Brentano, Ludwig Tieck addresses the theme of the animated statue in Der Runenberg (Rune Mountain), 1802 (Tieck [1985], 184-209). In Tieck's work, too, the Romantic world view comes to the fore, bringing the intensification of the everyday through the medium of art.

The young hunter Christian, the protagonist of Tieck's Der Runenberg is driven by an indeterminate longing for wide, unbounded spaces. This longing takes him away from his home to the mountains, where he comes near to the fulfillment of his dreams in a nocturnal vision on Rune Mountain. Before Christian's enraptured gaze, a pagan goddess arises in "otherworldly beauty" (Tieck [1985], 192) out of the "wreckage" (Tieck [1985], 192) of the past. The stones and ruins of the everyday world are thereby intensified, raised to a higher power, through the beauty of the animated woman of stone: 
naked, she at length began to walk up and down the hall, her heavy, flowing locks forming a dark, billowing sea around her, from which parts of her pure body shone at intervals like marble. (Tieck [1985], 192)

In Tieck as well, eroticism and love play a decisive role in the process of animation, for the marble woman becomes Christian's beloved. Once again, however, it is not a question of an actual, carnal union of the couple. In the place of gratified carnal love, we find anew the transformation of desire into art. On Rune Mountain, Christian makes a pact with the mysterious goddess which serves in the text to rival bourgeois marriage. The symbol of this pact is a tablet of runes, with cryptic writing marked in the stone. Woman and writing thus gain a "close metonymic connection" (Kremer [1996], 59), since the tablet serves as a substitute for the woman (cf. Appelt [1989], Kittler [1985]). By examining the rubies, diamonds and jewels, Christian succeeds in deciphering the "marvelously incomprehensible figures" (Tieck [1985], 192) and thus achieving a romantically intensified experience of reality. Through this reading, he accedes to the Romanticized, poeticized world:

Within him a chasm had opened of sights and sounds, of longing and sensual pleasure; a flock of winged notes, melancholic and joyful melodies, moved through his soul, which was agitated to its very base: he saw a world swelling with pain and hope, mighty, marvelous boulders of trust and defiant faith, great streams of water, flowing as though full of melancholy. (Tieck [1985], 192)

This passage clearly articulates what has been missing in Christian's everyday life, that experience of art he has long sought in vain and has finally found in the meeting with the goddess of runes.

Compared to this experience, the bourgeois marriage with a real woman can only be short-lived. Christian does leave Rune Mountain temporarily, but soon gives up the community of the valley and leaves his wife and child, spurred by the memory of the woman on the mountain. Christian's decision in favor of Rune Mountain, the tablet, and the woman from the rocks is to be read as a rejection of the everyday world in favor of the counter-world of Romantic poetry and art. This is not, however, unproblematic. For his wife and the people of the valley, Christian's decision causes unhappiness and pain (cf. Tieck [1985], 206f); from the bourgeois perspective, Christian is lost to "madness" (Tieck [1985], 206) and death. In this threatened loss of self at the end of the text, as well as in the suffering of the family community, Tieck signals that the Romantic appropriation of the other through art remains irreconcilable with social reality. The apotheosis of art is thus counterbalanced by skepticism.

\section{$* * *$}

The dangerous and corrupting aspect of the artificial woman comes repeatedly to the fore in the works of Achim von Arnim, E.T.A. Hoffmann and Joseph von Eichendorff (cf. Fink [1983], 104ff). In the work of these authors, all of whom belong to a later generation of German Romantics, the figure of the artificial bride increasingly slides into a sceptical and self-critical commentary on Romantic conceptions of art. The body to be animated is no longer a marble statue; in its place we now find dolls, automata and the Golem.

The Romantic beloved is usually a sublime figure of womanhood, her carnality transformed into an artistic ideal. Even in Brentano and Tieck, the artificial bride figures on the side of the sublime and the divine. But in the Venus statues, dolls and automata of Arnim, Hoffmann and Eichendorff the divine tips over into the monstrous; the spiritual becomes sexual, and life once intensified by art becomes an enervated mechanism of death. Arnim goes so far as to make this feature of his androids central to his work. For him, the artificial creature represents not the sublime but rather the earthly being shorn of spirituality.

In Achim von Arnim's story Isabella von Ägypten (Isabella of Egypt), 1812 (Arnim [1990], 622-744), the artificial bride appears as the figure of the Golem. The replacement of the statue by the Golem, a figure of clay, is itself important, since with the shift from classical mythology to Jewish legend (cf. Scholem [1992], Mayer [1987]) Arnim calls up a negative version of the Pygmalion theme. By activating anti-Jewish stereotypes (cf. Härtl [1987], Oesterle [1992]), Arnim makes the artistic creation fundamentally recognizable as a deficient being. Unlike the marble or ivory statue of the Pygmalion tradition, the animated Golem-woman of clay is not an improvement on her rival, but rather a worse form of her. Serving as the double (Doppelgänger) and copy of the gypsy queen Isabella, the Golem Bella is, in contrast to her angelic model, an unspiritual, purely instinctual being who incorporates 
merely the "crude embodiments" of human attributes in the form of "pride, lust and avarice" (Arnim [1990], 689).

In this substitution of the mortal for the divine, Arnim seeks to undermine the Romantic intensification of life represented by the artificial bride in Brentano and Tieck. Thus, the creation of Arnim's Golem is linked less to the Romantic inspiration that transcends borders than to its opposite: envy, jealousy, vengeance and betrayal. Arnim's protagonist, Archduke Karl, asks a Jewish sage to create the Golem as a means of deceiving his presumed rival in love, the Alraun. The Golem copy is then slipped unnoticed before the rival in place of the genuine Isabella. Karl enjoys his triumph by callously seducing the desirable Isabella (cf. Arnim [1990], 691), but this union has little to do with Romantic love except per negationem. In the figure of Isabella, Karl profanes the Romantic beloved, turning her into a sexualized, earthly bedfellow. Consistent with this logic, he soon confuses Isabella with the Golem copy, and spends his nights with the Golem of clay (cf. Arnim [1990], 704ff). As Isabella's double, Golem Bella thus reveals the destructive potential of carnal, earthly beings by fully displacing Isabella, who embodies the values of Romantic love.

Importantly, Arnim does not choose an arbitrary figure for the part of the male protagonist, but rather Karl V (1500-1558), the last, great late-medieval German emperor. Arnim thus makes a historical and philosophical connection between the decline of Romantic love and the demise of the medieval empire. When Karl V exchanges the gypsy queen Isabella for the Golem, he gambles away not only love, but also the glorious future of an extensive empire which would have joined the Occident with the Orient through the marital union of these royal offspring (cf. Andermatt [1996], 281ff). In imagining Karl V's failure to bring about this future, Arnim suggests the end of the Romantic dream of a unified European empire, though other German Romantics, such as Friedrich Schlegel writing in support of Metternich's restoration (cf. Schwering [1994], 549 and 554), would hold on to this dream for some time yet.

Arnim returns to the theme of the artificial bride in Raphael und seine Nachbarinnen (Raphael and his female neighbors), 1823 (Arnim [1992], 259-315). This story sketches the biography of the artist Raffael Sanzio (1483-1520) in terms of a process of sublimation from carnal life to the spiritual principle. The statue animation here appears both at the beginning and the end of Raphael's development, providing-much as in Brentano's Godwi-a commentary on the ideal course of the artist's biography. Surprisingly, the animated statue in Raphael und seine Nachbarinnen once again stands for the sublime, that purely spiritual and even divine element of being. This statue bears the features of the virtuous Benedetta, one of Raphael's two neighbors, with whom the young Raphael has fallen in love. The marble image is thus figured as the spiritual muse or divine mother. When Raphael attempts to paint the enchanting statue, she turns into the Madonna; in fact, all his future Madonnas, who establish Raphael's fame as a painter, will bear the features of the marble statue (cf. Arnim [1992], 275). As the sublime embodiment of Benedetta, the statue is a sublimation of the carnal body in the form of a painted Madonna. The earthly beloved is thus transfigured into the icon of Romantic art.

In a replay of the theme of the Venus ring, Arnim has Raphael place his engagement ring on the statue, seemingly for a lack of choice. Of his two neighbors, Benedetta, whom he has courted, is too easily shamed, while Ghita, a voluptuous baker's daughter who offers herself repeatedly as a rival to Benedetta, is too unashamed. Thus the ring lands-even if quite coincidentally-on the finger of the statue, who, in a clear reference to the process of sublimation, wears Benedetta's clothing (cf. Arnim [1992], 277). Arnim thereby claims that the artist must become engaged not to a mortal woman, but rather to the sublimated form of love, to art itself.

Arnim's story offers a three-stage developmental model for the artist's biography. The first stage consists of the engagement to the statue, combining the renunciation of marriage with the sublimation of love into art. In the second stage, the artist cultivates a non-binding, open exchange with love, which places the power of carnal love in the service of his art. In the last chapter, "Zu Raphaels Verklärung" (On Raphael's transfiguration) (Arnim [1992], 291), Raphael completes the transition to the third stage of artistry when, in a chapel, he once again comes across the marble statue of his youth. Wearing Benedetta's blue robe, she stands on the main altar as "the queen of Heaven" (Arnim [1992], 297) and "the holy mother without child" (Arnim [1992], 296). With a raised finger she reminds Raphael that he must not "any longer suspend his great work of transfiguration" (Arnim [1992], 297). The childlessness of the statue points again to the renunciation of marriage and earthly love. In the 
place of flesh-and-blood children we find the work of art, the sublimated Benedetta occupying the role of the mother or muse.

Arnim's representation of love, art and artistry clearly towes a great deal to the concepts of early German Romanticism. Such Romantic ideas of art subtend the critique in Raphael und seine Nachbarinnen, as becomes clear when one reads the other artists in the text as providing a contrasting commentary to the protagonist. This is particularly the case with the artist Bäbe, a deformed figure who serves as a grotesque double for Raphael. In a moment of dubious good fortune, Bäbe exploits his life for the sake of art, losing his humanity in the process. Bäbe, Ghita's renounced and scorned husband, nurtures an animalistic being in obscurity, painting in nightly episodes "indecent images from the history of the gods" (Arnim [1992], 304) as Raphael's alter ego. The "poor, baked Bäbe" (Arnim [1992], 307), who figures tellingly as Ghita's "ape" (Arnim [1992], 306), reflects the negative image of the artist Raphael, an existence degenerated to the animal or the automaton. In a classical image of fate, Bäbe's life hangs from a thread of the spindle which his wife Ghita has abandoned in order to enjoy herself elsewhere with suitors (cf. Arnim [1992], 306). The abandoned spindle, like the mightily rising dough and the flour-covered painter, add up to a grotesque, sexually symbolic inversion of the sublimation process in art. The "so-called ape in the corner" (Arnim [1992], 306), Bäbe, is Arnim's self-ironicizing response to the early Romantic conceptions of art which he instantiates in "Raphaels Verklärung."

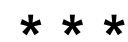

E.T.A. Hoffmann first takes up the theme of the artificial bride in his story Die Automate (The automaton), 1814. Here two friends, Ludwig and Ferdinand, are in deep discussion about the android musicians of Professor $X$ and conclude unanimously that the "dead, rigid aspect of mechanical music" (Hoffmann [1967], 372) has something "appalling" about it (Hoffmann [1967], 370). True art can only be "animated through the inner power of the soul ... which, of course, can never be the case with a machine" (Hoffmann [1967], 371). The clear verdict against the professor's experiments with automata fully corresponds with the Romantic conception of art, which rejects the rationalistic world view of the enlightenment; the friends thus see in the mechanical construction of the androids "a declaration of war against spirituality" (Hoffmann [1967], 371) which upholds philistine attitudes. The irony of Hoffmann's story, however, lies in the fact that at a decisive point the text throws this judgment into radical doubt by revealing that even Ferdinand's long-standing, secret love, an unknown singer, may well be one of Professor X's automata, much to the horror of the two friends.

The theme of the artificial bride reappears in a similar form in Hoffmann's Der goldene Topf (The golden pot), 1814, and in particular, of course, in Der Sandmann (The Sandman), 1815 (Hoffmann [1985], 11-49). While in Der goldene Topf it is the snake Serpentina who is transformed into a bride before the enraptured gaze of the artist, in Der Sandmann it is the mechanical doll Olimpia. The transformation of the snake Serpentina into the Romantic beloved touches on the android motif only tangentially, but Serpentina plays precisely the same role as the doll Olimpia in Der Sandmann; both are rivals to the actual human beloved. As versions of the artificial bride, Hoffmann's synthetic creations displace the bourgeois woman from the side of the Romantic hero. In one instance, this works out well, and in the other not so well. While his love for Serpentina allows Anselmus to be initiated into the correct relationship to writing and hence into his calling as a Romantic artist, Nathanael's love for Olimpia leads to self-destruction. The purification of Anselmus through art succeeds in setting him free from his bourgeois bride, a necessary liberation because Veronika would have tied Anselmus to the philistine world of office and marriage. His decision in favor of Serpentina is thus a decision for a life lived through art. Nathanael's love for Olimpia results in the same alienation from his bourgeois bride Clara, but it does not lead him away from the bourgeois world to the Atlantis of poetry. Rather-and Tieck has already warned us of this-it leads to madness and death.

The name Olimpia (the Italian spelling of "Olympia", meaning she who comes from Olympus), chosen by Hoffmann for his doll in Sandmann, clearly plays on the theme of the Venus statue, though here the "beauty of the ancient statue" is exchanged for an "automaton-like femininity" (Drux [1994], 23). Before the desiring gaze of Nathanael, Olimpia comes to life like the marble statue imagined by other Romantics, but, as in Arnim, this secularized, mechanical Venus proves to be dangerous. Hoffmann's texts, much more than the texts of Brentano, Tieck and Arnim, highlight the role of looking and the medium of sight as being important in the process of statue animation. Through the accumulation of images of eyes-including the robbing of sight as well as the substitution or simulation of eyes by 
glasses, mirrors, spectacles and telescopes (cf. von Matt [1971], 76ff)—such moments ironically and self-reflexively thematize the intensification of the Romantic aesthetic, thus exposing it to continuous reflection and criticism.

In the instance of statue animation in Sandmann, Nathanael is figured as both Narcissus and a voyeur, for he peeks through a telescope into Spalanzani's apartment in order to gaze at the beautiful Olimpia (cf. Hoffmann [1985], 36). It is precisely the intensification of his own gaze, this erotically sharpened, sedulous seeing, that awakens the dead doll to life. Hoffmann indicates this romanticizing act to be "an act of narcissistic transference of the eyes" in which "Nathanael [kindles] the fire of love in the lifeless automaton, in order subsequently to be able to ignite his own fire in the mirror all the more forcefully" (Kremer [1998], 82). The critical distance from early Romantic theories cannot be overlooked, for Hoffmann parodies them with his "autistic boundary or counterweight to magical idealism" (von Matt [1971], 105; cf. also 161).

The process is repeated and extended at Spalanzani's ball, where Olimpia is first presented to the public. In contrast to most of the ball-goers, who tend to sneer at the beautiful daughter of Spalanzani who sings and dances with "the soulless beat of a . . machine" (Hoffmann [1985], 42), Nathanael is carried away by rapture and passion. The recognition that Nathanael finds in Olimpia only his own love and "soul" (Hoffmann [1985], 40) does not seep into his consciousness, although he verges on such a recognition when he sees "his entire self reflected" (Hoffmann [1985], 40), or, ex negativo, when he remonstrates with the critics of his love that Olimpia's mechanical nature is simply the effect of soulless observation and hence the result of "one's own dullness" (Hoffmann [1985], 41).

Nathanael fully realizes that Olimpia appears desirable only to the person who has "a poetic soul" (Hoffmann [1985], 42), in comparison to which "cold, prosaic people" (Hoffmann [1985], 42) remain "rigid and soulless" (Hoffmann [1985], 41). But it remains concealed from him that he in fact loves a doll, an automaton, until he is finally and shockingly confronted with the materiality of the machine in the process of its grotesque disintegration:

Coppola now threw the figure over his shoulder and with a terrible, shrill laugh dashed down the stairs, dragging the feet of the figure, which hung loose in a hideous manner, clattering and echoing woodenly on every step.

Nathanael stood paralyzed. He had seen only too clearly that Olimpia's deathly pale, waxen countenance had no eyes, just dark holes—she was a lifeless doll. (Hoffmann [1985], 44f)

As a ruin, the machine is recognizable as a dead artifact, uninhabited by life. It is the life of her admirer Nathanael, the life of the artist, whose narcissistic self-consumption finally turns into a self-destructive mechanism of death. This process is symbolically underlined through the robbing of eyes, which ends in the loss of eyes, the loss of the Romantic gaze, and thus the loss of Romantic spirituality. After the destruction of the doll, Professor Spalanzani throws a pair of bloody eyes at Nathanael's chest, which then lie on the floor and stare at him; the gesture is accompanied by the words, "the eyes that have been stolen from you ... - -there you have the eyes!" (Hoffmann [1985], 45). This brutal denunciation of Romantic intensification as a form of self-deceit is too much for Nathanael, and he goes hopelessly mad: "Thus in this condition of insane fury he was taken raving to the madhouse" (Hoffmann [1985], 45).

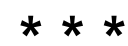

In Joseph von Eichendorff's novella Das Marmorbild (The marble statue), 1819 (Eichendorff [1998], 29-82), the artificial bride, as in Tieck, originates as a "pagan goddess" (Eichendorff [1998], 79) arising from ancient "ruins" (Eichendorff [1998], 76), which are even designated as "having been the temple of Venus" (Eichendorff [1998], 79). The protagonist Florio, transformed by his new love for the young Bianka, ends up on a moonlit night outside the city of Lucca, unbeknownst to him in the enchanted circle of Venus. A "statue of Venus, made of marble" (Eichendorff [1998], 45) stands on the edge of a fishpond "as though the goddess had just risen from the waves" (Eichendorff [1998], 45). Florio is completely enchanted by the statue, and his enraptured gaze sets the process of animation unexpectedly in motion. The marble Venus appears to open her "soulful eyes" (Eichendorff [1998], 45) and the beautiful limbs seem to take on a warmth of their own. On closer inspection, however, the 
marble statue proves to be "appallingly white and motionless" (Eichendorff [1998], 46) and looks "fearfully with stony eye sockets out of a boundless stillness" (Eichendorff [1998], 46).

The dangerous dialectic of Romantic intensification takes an exemplary form in Eichendorff. In his work, "melancholy and delight" (Eichendorff [1998], 46) turn one into the other with no mediation, in a "horror that is never felt" (Eichendorff [1998], 46); life changes place with death. As with Hoffmann's Nathanael, what is here manifested is the dangerously narcissistic dimension of artistic animation. Caught up by the Venus statue, Florio's love has receded from the human counterpart, the girl Bianka, and turned into a fantastically heightened but lonely self-love. In Eichendorff, too, this leads to madness, death and depravity.

After the nocturnal meeting with Florio, the stone Venus awakes and begins to lead her own life, uncontrolled by social mores. It is the dark knight Donati who finally arranges a romantic encounter between Florio and "the beautiful lady" (Eichendorff [1998], 53). Venus leads Florio "into the interior of her castle" (Eichendorff [1998], 69), dominated by the pagan art world and sultry eroticism. In Venus' love chamber he finds a "row of marble statues" (Eichendorff 1998, 70) and walls covered in "exquisite tapestries worked in silk with life-sized histories of exceptional vividness" (Eichendorff [1998], 70). The love encounter itself is preceded by a discussion about art. In the pictures of Venus' chamber, Florio sees the embodiment of the image world of his youth, all "his youthful dreams" (Eichendorff [1998], 71); what he had dreamed before seems now suddenly able to "come to life" (Eichendorff [1998], 71). The nocturnal scene, however, soon turns uncanny. Thunder approaches, and in a flash of lightning the beloved changes again into a marble woman, the cold stone looking at Florio partly "smiling" and partly with "a dreadful face" (Eichendorff [1998], 72). In a nightmarish vision all the figures of the room come to life- the marble statues and tapestry images, even down to the flowers and candelabra. In this ghostly metamorphosis, the art world of Venus begins to press itself onto Florio, who is caught in the grip of a "deathly terror" (Eichendorff [1998], 73):

the two arms, which held the candles, twisted and stretched out longer and longer, as though a monstrous man were working his way out of the wall; the room filled up more and more, the flashes of lightening threw horrifying shadows amongst the figures. Through the throng Florio saw the statues throw themselves toward him with such violence that it made his hair stand on end. (Eichendorff [1998], 73)

Florio runs away, back to life, and thus saves himself from a Romantic art world become excessively powerful. He barely escapes madness and death, but falls temporarily into a deep depression. Nothing remains of Venus' world but ruins and wreckage. At the end Donati's counterpart, Fortunato, informs Florio of the persistent danger, explaining that "the spirit of the beautiful pagan goddess" arises every spring from the ruins, out of "the dreadful stillness of the grave", to corrupt "young, carefree souls with satanic delusions" (Eichendorff [1998], 79); these young men "lose life and soul, roam aimlessly, and waste away in horrible self-deception" (Eichendorff [1998], 79).

Eichendorff's text can be read as a commentary on the Romantic treatment of art as though it were a religion. The pagan Venus represents the dismissal of a conception of art which in Eichendorff can only lead to the destruction of the artist, his social isolation and his spiritual confusion. In Fortunato's closing song, Eichendorff turns to a counter-image, "another image of woman" (Eichendorff [1998], 78); in place of Venus, we find the Virgin Mary:

For over land and sea / There appears, so still and mild / High above the rainbow, / Another image of woman. / A child in her arms, / The miraculous unfolds, / And the compassion of heaven / Pervades the whole world. (Eichendorff [1998], 78f)

The Catholic mother of God captures the pagan Venus and dispels her, and with her the world of Romantic art. With her help, Florio finds his way back to life. The text ends by allowing Florio to rediscover the worth of his real bride Bianka, who has only been temporarily displaced by Venus. The story triumphantly celebrates the happiness of the young couple. With this moment, the religion of art preached by German Romanticism comes to an end, pushed once again to the margins of convention.

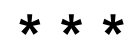


Outside the German-speaking world, the Romantic animated statue appears only infrequently. In fact, Prosper Mérimée's story La Vénus d'Ille (The Venus of Ille), 1837 (Mérimée [1969], 19-56), is the only text which is clearly in line with the German thematic tradition. As part of the French reception of E.T.A. Hoffmann, the fantastic found its way to the center of Mérimée's stories. Accordingly, Todorov calls La Vénus d'Ille a consummate example of the ambiguity of the fantastic (cf. Todorov [1970], 49). In this ambiguity, the natural and the supernatural come into conflict as two irreconcilable orders. Mérimée's story relies on the fact that the reader never knows, up to the end and beyond, whether the animated statue of the text should be taken as real or as a fantasm. This conflict of interpretation on the one hand places the rational, scientific world into question while, on the other hand, it proves to be an artistic "game with the fictional consciousness of the modern reader" (Pening [1980], 43).

Mérimée's literary game with the enlightenment reader is in large part the French variation and extension of German transcendental poetry. In Mérimée, too, the animation of the Venus statue, which is fully self-reflexive, poses the question of the appropriate relation between life and art. In the place of the Romantic artist, who must choose between the real and the ideal bride, we find in Mérimée the scientist, and with him the question of the validity of his rational judgment. The narrator of the tale is a Parisian archaeologist and bachelor. With the superior self-confidence of the city dweller on a journey to the provinces, he meets a colleague dabbling in art, M. de Peyrehorade, who with great pride shows him an ancient statue of Venus which he has discovered. In the ensuing quarrel between the two scholars about the correct classification and interpretation of the bronze statue, Mérimée opens to debate not only the scientific world but also, more self-reflexively, the reception of his own text. For the quarrel over Venus is a quarrel about the correct interpretation of writing, revolving around the meaning of a Latin inscription on the statue itself. Just as the narrator and M. de Peyrehorade cannot agree on how to read the inscription and hence how to understand the Venus statue, so the reader, faced with the ambivalence of the fantastic in Mérimée's tale, cannot decide on a single course of reading. M. de Peyrehorade, the captious and pedantic rationalist who claims the right of interpretation to himself alone, ends up cruelly punished. In terms of poetic self-reflexivity, this serves as a warning to the reader not to find him/herself in a similar situation.

In Mérimée it is no longer love that drives the meeting between the scientist and Venus, but ratherthough hidden behind the rules of civilized politesse-the polarizing passions of competition, battle, will to power, wealth and career. Mérimée's text suggests in drastic fashion that Venus has no patience with such passions, since this Venus takes vengeance on and finally kills everyone who slights her and love. The victim of Mérimée's Venus, however, is only indirectly the scientist. In a structural displacement, the revenge of Venus lands on M. Alphonse, the son of M. de Peyrehorade. $M$. Alphonse repeats in a different sense the same message already provided by the father. He is on the cusp of marrying an enchanting young woman, but he is only doing so for the money. On the day of the wedding his passion is entirely involved in a competitive game, a "tennis match" (Mérimée [1969], 42), which he plays with ambition and drive, and, true to form, wins. Into this context Mérimée introduces the motif of the Venus ring. In order to be able to devote himself without hindrance to the game, Alphonse slips off his expensive engagement ring and sticks it for the time being on the finger of the Venus statute. The text us leaves in no doubt that in this act love has been sacrificed for the sake of battle:

And his bride? . . Truly, I believe he would have postponed the wedding had it been necessary. I watched him hurriedly pull on a pair of sandals, roll up his sleeves, and with a confident air place himself at the head of the vanquished party, like Caesar rallying his troops at Dyrrachium. (Mérimée [1969], 43)

In a subversion of the process of civilization, the competitiveness of the scientist is displaced onto the competition between the tennis players, and then onto the scenario of an ancient battle. In the process, wedding, bride and love are forgotten. At this point Venus vengefully intervenes. She balls up her hand, refuses to release the ring, and climbs that night into the conjugal bed, next to the newly wedded wife, where she proceeds cruelly to strangle the bridegroom who has forgotten love. As the horrified bride reports the next morning,

She heard a choked cry. The figure by her side in the bed raised itself up and seemed to stretch its arms out. She turned her head at that point ... and saw, she says, her husband on his knees by the bed, his head level with the pillow and violently clamped between the arms of a greenish giant. She says —over and over twenty times, the poor woman! —-that she recognized the figure ... Can you guess? It was the bronze Venus, M. de Peyrehorade's statue. (Mérimée [1969], 53) 
The terrible end to the ambitious bridegroom, as competitive in sport as in money matters, remains unexpiated. Venus stands triumphant in the garden in her original place:

Every time that I passed by the statue, I [the narrator] stopped for a moment to look at it. This time, I confess, I could not look at the expression of spiteful mockery without horror. With my head full of the terrible scenes to which I had been witness, it seemed to me that I saw an unholy demon gloating over the misfortune that had struck this house. (Mérimée [1969], 52)

The narrator remains puzzled by the situation, even as he leaves the site of the event. His perplexity is transferred to the reader, who is thus left in the dark about what has really happened. Nonetheless, the rational explanation offered for the murder, though convincing at first, is vigorously refuted. The probable murderer, a competitor whom Alphonse humiliated in the tennis match, is provided with a hard and fast alibi. When M. de Peyrehorade dies not long after and the pagan statute is melted down into a church bell, Venus still continues to wreak havoc; the ringing bell causes the grapevines in the area to freeze. The reader, of course, knows that Alphonse drank a great deal; in fact, on his wedding night, he had gone to bed drunk ...

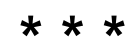

In addition to Prosper Mérimée's version of the artificial bride, there are two other non-German texts that are of pre-eminent importance in this context, even though—or precisely because-they subvert the thematic tradition. These texts are Mary Shelley's Frankenstein, or the Modern Prometheus, 1817 (Shelly [1993]) and a later novel, belonging to the fin de siècle, L'Ève Future (Tomorrow's Eve), 1886, by Jean-Marie Villiers de I'Isle-Adam.

At first glance, Mary Shelley's monster seems to have nothing to do with an animated bride, and certainly nothing to do with a seductive Venus. As the title indicates, Shelley's text turns not on the paradigm of Pygmalion, but on the other classical myth of human creation, the myth of Prometheus. Since Goethe's similarly titled hymn to genius, Prometheus has figured as a provocative symbol of bourgeois emancipation, "the exponent of a humanity which strives for social, political and spiritual self-determination" (Schmidt [1988], 264). In the history of the mind, Prometheus testifies to the Enlightenment of the eighteenth century. The stealing of the gods' fire out of which the self-made man is shaped and animated exemplifies the autonomous consciousness of the enlightenment subject, who is self-illuminating and independent of divine powers-that-be. As the modern Prometheus, Mary Shelley's Dr. Frankenstein stands for the crisis of the enlightenment subject. The novel launches a radical critique, from a Romantic perspective, of the human will to self-determination.

Shelley's protagonist Victor Frankenstein, the inventor of the monster, is "the prototype of any number of mad professors who populate science-fiction literature" (Grawe [1986], 313). His primary characteristic is cold passion, a feverish approach to work that excludes love. In this Frankenstein dreams less of wealth than of "glory" (Shelley [1993], 59):

So much has been done, . . -more, far more, will I achieve: treading in the steps already marked, I will pioneer a new way, explore unknown powers, and unfold to the world the deepest mysteries of creation. (Shelley [1993], 73)

To achieve his goal, Frankenstein grasps, like Faust, at every kind of knowledge available to humanity. He studies not only the natural sciences, but has fully researched alchemy and natural philosophy. In the end he commits himself to the contemporary science with the greatest future, chemistry, and links the knowledge he acquires there with the study of anatomy:

My attention was fixed upon every object the most insupportable to the delicacy of the human feelings. I saw how the fine form of man was degraded and wasted; I beheld the corruption of death succeed to the blooming cheek of life; I saw how the worm inherited the wonders of the eye and brain. (Shelley [1993], 78)

Frankenstein wants to "examine the causes of life" (Shelley [1993], 78) although, to do so, he turns cold-bloodedly to death and destruction. Unlike the Romantic artists represented in the works of Brentano, Tieck, Arnim, Hoffmann and Eichendorff, Frankenstein's gaze does not radiate animating 
flames of love but rather observes in cold emotion the passage from life to death: "I paused, examining and analyzing all the minutiae of causation" (Shelley [1993], 78). In consequence, he actually acquires the ability to "bestow] animation upon lifeless matter" (Shelley [1993], 78), but only to the extent that he engages unflinchingly with death. He thus seeks out body parts in anatomy classrooms and cemeteries, all the while coming ever closer to death in his own self-image:

My cheek had grown pale with study, and my person had become emaciated with confinement. ... Sometimes I grew alarmed at the wreck I perceived that I had become; the energy of my purpose alone sustained me. (Shelly [1993], 80f, 83)

As though mirroring the gradual development of his creation, Frankenstein's appearance takes on the morbid hideousness of the monster before it even appears. Shelley's text thus clearly draws on the narcissistic dimension of android creation. The result of Frankenstein's efforts, however, is absolute hideousness, the sheer opposite of the superhuman beauty which emanates from the animated Venus statue. Frankenstein describe the creature that his cold passion has finally succeeded in animating as follows:

How can I describe my emotions at this catastrophe, or how delineate the wretch whom with such infinite pains and care I had endeavored to form? His limbs were in proportion, and I had selected his features as beautiful. Beautiful! — Great God! His yellow skin scarcely covered the work of muscles and arteries beneath; his hair was of a lustrous black, and flowing; his teeth of a pearly whiteness; but these luxuriances only formed a more horrid contrast with his watery eyes, that seemed almost the same colour as the dun white sockets in which they were set, his shrivelled complexion, and straight black lips. (Shelley [1993], 85)

That the "watery eyes" are at the center of this hideous being is telling, for the "watery" eye of the monster corresponds to the cold eye of the scientist, in contrast to the "fiery" eye of love possessed by the Romantic artist and the bride-statue he has brought to life. What Frankenstein is missing is love; his creation is therefore not a wonderful bride with radiant, loving eyes, but a hideous monster with a milky gaze. If one adds to this the narcissistic dimension of the process of creation, then the monster comes to stand for unconcealed self-loathing.

Mary Shelley illustrates the opposition between cold rationality and rapturous love in a way similar to that of Mérimée's later Venus, for Victor Frankenstein constantly postpones marriage to his fiancée Elizabeth on the grounds of his scientific passion. Rather than marry her and surrender himself to love, Frankenstein pursues the creation of his monster in place of going to the bride who waits for him in a distant university town:

The summer months passed while I was thus engaged, heart and soul, in one pursuit . . . And the same feelings which made me neglect the scenes around me caused me also to forget those friends who were so many miles absent, and whom I had not seen for so long a time. I knew my silence disquieted them .... I I wished as it were, to procrastinate all that related to my feelings of affection until the great object, which swallowed up every habit of my nature, should be completed. (Shelley [1993], 81, 82)

The monster is as much a rival of the bride as is the animated Venus statue of the German Romantics. It is thus only logical that Mary Shelley's monster should enter Frankenstein's conjugal bed on his wedding night and kill the bride. And, like Mérimée's Venus, vengeance here also triumphs:

The shutters had been thrown back; and, with a sensation of horror not to be described, I [Frankenstein] saw at the open window a figure the most hideous and abhorred. A grin was on the face of the monster; he seemed to jeer, as with his fiendish finger he pointed towards the corpse of my wife. (Shelley [1993], 262)

To the extent that Mary Shelley replaces Pygmalion by Prometheus, she succeeds in radically subverting the thematic tradition. In her work, "the transformation of the Pygmalion myth into a destructive version" (Stephens [1997], 532), intimated in the works of all the Romantics, finds its most complete form. The figure of the enraptured lover is replaced by the ambitious careerist, the artificial bride by the murderous monster, and narcissistic love by self-loathing. 
Jean-Marie Villiers de l'Isle-Adams' L'Ève Future, 1886 (Villiers [1986], 763-1017), adapts the artificial bride of the Romantics in virtuoso fashion to the fin de siècle. At the end of the nineteenth century, the novel returns to the Romantic discussion about art and life by shifting the counter-world of the ideal from the realm of art to that of science and technology. In a neo-romantic gesture, the natural world is self-consciously declared to be obsolete. It is no longer the artist and art, however, but the scientist and technological advancement which will allow humanity to move out of the old world and into the ideal.

Villiers takes up both the Pygmalion and the Prometheus myth together. His protagonist, Lord Ewald, is the lover who, like Pygmalion, has been disappointed in a real woman and finds himself enraptured by the merits of the artificial woman. In the role of the modern Prometheus, we find the figure of the inventor Thomas Alva Edison, who has brought Promethean fire to the people in the form of electricity. Lord Ewald, however, is no artistic type; he is rather a wealthy decadent who is weary of life and want to kill himself because of his disappointment with women. Because of Edison he survives his disappointment, for Edison puts his immense knowledge and newest technological discoveries to work in the creation of the ideal woman whom Ewald has been seeking in vain in the real world.

Edison's synthetic Miss Hadaly originates in a way similar to Arnim's Golem Bella, for both are copies of a living model. Unlike Arnim's Isabella, however, the original in L'Ève Future, Alicia Clary, represents the frailty of the female sex. She comes across as a fully insipid "bourgeoise" (Villiers [1986], 808), whose single attractive attribute is an impeccably beautiful body. Alicia, as the "bourgeois goddess" (Villiers [1986], 804) and the cause of Lord Ewald's disappointment, thus continues the series of bourgeois women reviled by the Romantics. Her surname Clary is an obvious pun on Hoffmann's Clara in Der Sandmann, who represents the species at large. Edison's creation Hadaly, whose name means "the IDEAL" (Villiers [1986], 852), is intended to incorporate the bodily beauty of the model while making up for the deficiencies of the actual woman. As Edison explains to his friend Lord Ewald,

"I will make a perfect reproduction of this woman [i.e. Alicia], a double of her, with the sublime aid of Light!. . In this vision, I will make the Ideal manifest, for the first time, before your senses, PALPABLE, AUDIBLE AND MATERIALIZED." (Villiers [1986], 836)

In order to achieve the goal of materializing the Ideal, like the task of squaring the circle, Edison draws on the achievements of the most up-to-date technology. Over the course of several pages, Villiers' text describes in minute detail the components which make up the "magneto-metallic organism" (Villiers [1986], 856) of this new fantasy woman. The model once again is nature, though Edison compensates for and improves on organic life with the help of inorganic wires, metal, glass and technology. Electricity, "this spark bequeathed by Prometheus" (Villiers [1986], 910), provides the life force. Here the text focuses attention in particular on breathing and language:

"This spark, bequeathed by Prometheus, which you see here captured and running along this magical wand, produces breathing by affecting the magnet which is situated vertically between the two breasts and which attracts the nickel blade attached to this steel sponge; at each moment the sponge falls back into place because of the regular intervention of this isolator .... Here are the two gold phonographs, inclined at an angle toward the center of the chest, which form the two lobes of Haday's lungs. They pass one to the other the metallic leaves of their harmonious-I would even say heavenly-conversations, somewhat like printing presses draw pages from one side to the other. A single tin band can contain seven hours of such speech. These words come from the minds of the greatest poets, the most subtle metaphysical thinkers, and the most profound novelists of this century, all geniuses to whom I have turned-and who have surrendered to me, at great cost, these marvels which have never before been printed.

"This is why I say that Hadaly is not an intelligence, but the Intelligence." (Villiers [1986], 910)

Electricity and technology are the heirs of literature and philosophy, so that in the end it is not art but the technological world that guarantees survival for the disappointed lover Ewald. Edison himself stands for this dawning of art within science, since his face reminds one in "a striking manner" (Villiers [1986], 767) of Gustave Doré, so that one finds in Edison "the face of the artist translated into the face 
of the scholar" (Villiers [1986], 767). As a new Eve created by Edison's compassion, the robot woman Hadaly is a fully synthetic art creation, an android who gratifies male fantasies in every sense.

Nonetheless, it takes more than Edison's knowledge to bring life to the artificial creature; it also require the enraptured love of Lord Ewald because Hadaly, like Hoffmann's Olimpia, is essentially a narcissistic mirror, who simply sends back to the man what he needs from her. In response to Ewald's question about how the automaton will be able to find the right words to converse with him, Edison answers,

"The word you expect-and for this the beauty will depend on your own suggestion—will be the word with which she responds! Her 'consciousness' will no longer be the negation of your own, but will become the semblance of the soul which best fits your melancholy. You will be able to evoke in her the radiance of your own love, without doubting, this time, that she will refute your dreams! . . It will not even be necessary for you to speak the words! Her words will respond to your thoughts as well as to your silences." (Villiers [1986], 913)

The animated Hadaly explains the same point to Ewald, who is still sceptical:

"You see, in response to your despair, I hurried to clothe myself in the radiant lines of your desire ... What am I? ... A creature from a dream who glimmers in your thoughts-and whose beneficent shadow you can dissipate with one of those nicely-turned arguments, which will only leave you, in place of having me, with emptiness and weary tedium, the fruits of a pretense of truth. . . My being, here below, at least for you, depends on your free choice. Affirm my being, tell me that I am! Strengthen my being through your own! And suddenly I will be fully alive before your eyes, real to the degree that your creative will has penetrated through me. Like a woman, I will be for you only that which you believe me to be." (Villiers [1986], 990f)

In addition to the cold technology of the Promethean Edison, it requires the warm love of the Pygmalion Ewald to succeed in creating the ideal woman. Mary Shelley had shown in drastic measure what happens when the latter is lacking.

Nonetheless, Villiers' novel also ends in catastrophe. At first, indeed, Lord Ewald steers a course with his artificial ideal woman towards an avowed happiness for both, unthreatened by any danger, and fully in opposition to the Romantic thematic tradition. Hadaly is then put into a sleep-like state by Edison in order to travel with Ewald in a "coffin" or "sarcophagus" (Villiers [1986], 1001) by ship from New York to England, where they plan to live in perfect happiness on Ewald's estate. The morbid scenario is thus foreshadowed, for in fact things turn out differently than planned. The ship sinks, taking Hadaly with it, and Ewald, who survives the catastrophe, remains in a stupor of grief over the loss of his ideal. This abrupt and unmotivated ending has been read to mean that Villiers, as artist and author of novels, could not allow the grand victory of technology, even in relation to the imagination, over art (cf. Gendolla [1984], 270). From the perspective of literary history, however, Hadaly's sad end follows clearly in the tradition of Romantic self-reflection and self-criticism. Conceiving of the imaginary realm in terms of the hero's crossing into the counter-world of art has always been bound up with death and danger, from Brentano to Eichendorff. This holds no less true for Villier's Lord Ewald, for whom the transition into the world of the ideal can end only in grief and disappointment. From the perspective of culture studies, the sinking of the ship at the end of Villier's novel can be read as a sceptical commentary on the Faustian pursuit of science and technology. According to Viller's text, these are not to be relied upon, since nature, embodied in the storm-tossed ocean and the conflagration on board the ship, is always stronger in the end. Romanticism has throughout used the figure of the artificial woman to draw our attention to the fact that the move into the counter-world of the ideal, bound up as it is with the rejection of nature, too readily means giving oneself up to death. This obviously holds true even when technology replaces art.

(Trans. Misha Kavka)

\section{Bibliography}


- Andermatt, Michael. 1996. Verkümmertes Leben, Glück und Apotheose. Die Ordnung der Motive in Achim von Arnims Erzählwerk. Bern, Frankfurt am Main, New York, Paris: Lang.

- Appelt, Hedwig. 1989. Die leibhaftige Literatur. Das Phantasma und die Präsenz der Frau in der Schrift. Weinheim/Berlin: Quadriga.

- Arnim, Achim von. 1990. Die Novellensammlung von 1812. Sämtliche Erzählungen 18021817. Ed. by Renate Moering. Frankfurt am Main: Deutscher Klassiker-Verlag. 611-893.

- Arnim, Achim von. 1992. Raphael und seine Nachbarinnen. Sämtliche Erzählungen 18181830. Ed. by Renate Moering. Frankfurt am Main: Deutscher Klassiker-Verlag. 259-315.

- Böhme, Hartmut / Gernot Böhme. 1985. Das Andere der Vernunft. Zur Entwicklung von Rationalitätsstrukturen am Beispiel Kants. Frankfurt am Main: Suhrkamp.

- Brentano, Clemens. 1973. Godwi oder Das steinerne Bild der Mutter. Ein verwilderter Roman von Maria. Werke. Studienausgabe. Ed. by Friedhelm Kemp. Vol. 2. München: Hanser. 7-459.

- Brunel, Jean. 1969. Notice. Mérimée, Prosper. La Vénus d'llle. Carmen. Ed. by Jean Brunel. Paris: Larousse. (Nouveaux Classiques Larousse). 9-18.

- Drux, Rudolf (Ed.). 1988. Menschen aus Menschenhand. Zur Geschichte der Androiden. Texte von Homer bis Asimov. Stuttgart: Metzler.

- Drux, Rudolf. 1994. Erläuterungen und Dokumente. E.T.A. Hoffmann: Der Sandmann. Stuttgart: Reclam.

- Eichendorff, Joseph von. 1998. Das Marmorbild. Sämtliche Werke. Historisch-kritische Ausgabe. Ed. by Wilhelm Kosch, August Sauer, Hermann Kunisch, Helmut Koopmann. Bd. 5.1. Erzählungen. Erster Teil. Ed. by Karl Konrad Polheim. Tübingen: Niemeyer. 29-82.

- Fink, Gonthier-Louis. 1983. Pygmalion und das belebte Marmorbild. Wandlungen eines Märchenmotivs von der Frühaufklärung bis zur Spätromantik. Aurora 43, 92-123.

- Freud, Sigmund. 1970. Das Unheimliche. Studienausgabe. Bd. IV. Frankfurt am Main: Fischer. 241-274.

- Gendolla, Peter. 1984. 'Das strahlende Äußere deines Verlangens'. Jean-Marie Villiers de I'Isle-Adam: Die Eva der Zukunft. Deutsch von Annette Kolb. Mit einem Nachwort von Peter Gendolla. Frankfurt am Main: Suhrkamp 1984 (Phantastische Bibliothek 108). 265-271.

- Härtl, Heinz. 1987. Romantischer Antisemitismus. Arnim und die Tischgesellschaft. Weimarer Beiträge 33/7, 1159-1173.

- Hoffmann, Ernst Theodor Amadeus. 1967. Die Automate. Werke in vier Bänden. Ed. by Herbert Kraft, Manfred Wacker. Bd. 2: Nachtstücke. Klein Zaches genannt Zinnober. Die Serapionsbrüder. Frankfurt am Main: Insel. 352-378.

- Hoffmann, Ernst Theodor Amadeus. 1985. Der Sandmann. Sämtliche Werke in sechs Bänden. Ed. by Wulf Segebrecht, Hartmut Steinecke, Gerhard Allroggen, Ursula Segebrecht. Bd. 3. Nachtstücke. Klein Zaches. Prinzessin Brambilla. Werke 1816-1820. Ed. by Hartmut Steinecke, Gerhard Allroggen. Frankfurt am Main: Deutscher Klassker Verlag. 11-49.

- Kittler, Friedrich A. 1985. Aufschreibesysteme 1800/1900. München: Fink.

- Kremer, Detlef. 1996. Prosa der Romantik. Stuttgart, Weimar: Metzler.

- Kremer, Detlef. 1998. E.T.A. Hoffmann zur Einführung. Hamburg: Junius.

- Mayer, Sigrid. 1987. Golem. Enzyklopädie des Märchens. Handwörterbuch zur historischen und vergleichenden Erzählforschung. Ed. by Rolf Wilhelm Brednich. Vol. 5. Berlin, New York: de Gruyter. 1387-94.

- Mérimée, Prosper. 1969. La Vénus d'Ille. Carmen. Ed. by Jean Brunel. Paris: Larousse. (Nouveaux Classiques Larousse). 19-56.

- Mérimée, Prosper. 1985. Die Venus von Ille. Die Venus von Ille und andere Novellen. Aus dem Französischen von Arthur Schurig. Zürich: Diogenes. 279-327.

- Mühlher, Robert. 1957. Der Vernusring. Zur Geschichte eines romantischen Motivs. Aurora $17,50-62$.

- Oesterle, Günter. 1992. Juden, Philister und romantische Intellektuelle. Überlegungen zum Antisemitismus in der Romantik. Athenäum 2, 55-89.

- Ovid. 1988. Metamorphosen. Epos in 15 Büchern. Übersetzt und ed. by Hermann Breitenbach. Stuttgart: Reclam. (Reclams Universal Bibliothek, 356)

- Penning, Dieter. 1980. Die Ordnung der Unordnung. Eine Bilanz zur Theorie der Phantastik. Phantastik in Literatur und Kunst. Ed. by Christian W. Thomsen and Jens Malte Fischer. Darmstadt: Wissenschaftliche Buchgesellschaft. 34-51.

- Schmitz-Emans, Monika. 1993. Der neue Pygmalion und das Konzept negativer Bildhauerei. Zu Varianten des Pygmalionstoffes in der modernen Literatur. Zeitschrift für deutsche Philologie 112/2, 161-187.

- Scholem, Gershom. 1992. Zur Kabbala und ihrer Symbolik. Frankfurt am Main: Suhrkamp. 
- Schwering, Markus. 1994. Romantische Geschichtsauffassung - Mittelalterbild und Europagedanke. Romantik-Handbuch. Ed. by Helmut Schanze. Stuttgart: Kröner. 541-554.

- Shelley, Mary. 1993. Frankenstein; or the Modern Prometheus. The Essential Frankenstein. Ed. by Leonard Wolf. New York: Plume.

- Shelley, Mary. 1986. Frankenstein oder Der moderne Prometheus. Aus dem Englischen übersetzt von Ursula und Christian Grawe. Anmerkungen und Nachwort von Christian Grawe. Stuttgart: Reclam.

- Sprengel, Peter. 1977. Maschinenmenschen. Ein zentrales Motiv in Jean Pauls Satire. Jahrbuch der Jean-Paul-Gesellschaft 12, 61-103.

- Stephens, Anthony. 1997. Frankenstein und Pygmalion. Pygmalion. Die Geschichte des Mythos in der abendländischen Kultur. Ed. by Mathias Mayer / Gerhard Neumann. Freiburg im Breisgau: Rombach. 531-553.

- Tieck, Ludwig. 1985. Der Runenberg. Schriften in zwölf Bänden. Ed. by Manfred Frank, Paul Gerhard Klussmann, Ernst Ribbat, Uwe Schweikert, Wulf Segebrecht. Bd. 6. Phantasus. Ed. by Manfred Frank. Frankfurt am Main: Deutscher Klassiker Verlag. 184-209.

- Todorov, Tzvetan. 1972. Einführung in die fantastische Literatur. München: Hanser (Literatur als Kunst).

- von Matt, Peter. 1971. Die Augen der Automaten. E.T.A. Hoffmanns Imaginationslehre als Prinzip seiner Erzählkunst. Tübingen: Niemeyer (Studien zur deutschen Literatur, 24).

- Villiers de I'Isle-Adam, Jean-Marie. 1986. L'Ėve Future. In: Fuvres complètes. Ed. by Alan Raitt, Pierre-George Castex, Jean-Marie Bellefroid. Paris: Gallimard. (Bibliothèque de la Pléiade, 328). 763-1017.

- Villiers de I'Isle-Adam, Jean-Marie. 1984. Die Eva der Zukunft. Deutsch von Annette Kolb. Mit einem Nachwort von Peter Gendolla. Frankfurt am Main: Suhrkamp. (Phantastische Bibliothek, 108).

- Völker, Klaus (Ed.). 1971. Künstliche Menschen. Dichtungen und Dokumente über Golems, Homunculi, Androiden und liebende Statuen. München: Hanser.

- Weschta, Friedrich. 1916. Eichendorffs Novellenmärchen "Das Marmorbild". Prag: KoppeBellmann. (Prager Deutsche Studien, 25). 